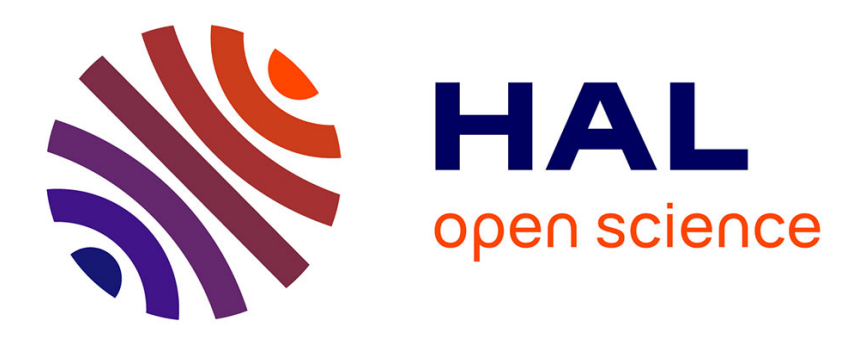

\title{
Ideological Materiality at Work: A Lacanian Approach
} Edouard Pignot

\section{To cite this version:}

Edouard Pignot. Ideological Materiality at Work: A Lacanian Approach. Working Conference on Information Systems and Organizations (ISO), Dec 2016, Dublin, Ireland. pp.93-107, 10.1007/978-3319-49733-4_6. hal-01619199

\section{HAL Id: hal-01619199 \\ https://hal.inria.fr/hal-01619199}

Submitted on 19 Oct 2017

HAL is a multi-disciplinary open access archive for the deposit and dissemination of scientific research documents, whether they are published or not. The documents may come from teaching and research institutions in France or abroad, or from public or private research centers.
L'archive ouverte pluridisciplinaire HAL, est destinée au dépôt et à la diffusion de documents scientifiques de niveau recherche, publiés ou non, émanant des établissements d'enseignement et de recherche français ou étrangers, des laboratoires publics ou privés. 


\title{
Ideological Materiality at Work: A Lacanian Approach
}

\author{
Edouard Pignot ${ }^{1}$ \\ ${ }^{1}$ Warwick Business School, Coventry \\ edpignotegmail.com
}

\begin{abstract}
While recent theoretical debates have foregrounded sociomaterial studies and the interpenetration between the social and the material, practicebased studies have neglected, if not omitted, the place of affect and ideology in work practice. The use of the notion of materiality causes a conflation of different ontological claims, and a conceptual clarification is needed to grasp the polysemy of materiality. This paper provides some key notions for those interested in addressing the materiality of the affective register at work. By drawing on authors such as Lacan, Althusser, Butler and the Essex Lacanian School, this paper suggests that much is to be gained by addressing two difficult but crucial notions: the materiality of the signifier and ideological fantasy.
\end{abstract}

Keywords: materiality $\cdot$ ideology.

\section{$1 \quad$ Introduction}

The key word of this conference is of course "beyond"; what is problematic is not so much the validity or obsolescence of interpretive studies in information systems (IS), but rather the difficulty of initiating new debates within the interpretive scope. Interpretivism, the research avenue which sees knowledge of reality as a social construction and states that value-free data cannot be obtained, stands in stark contrast with positivist studies, where "objective" data can be used to test a prior hypothesis (Walsham [1]). Although our field absolutely needs an interpretive label externally to define itself vis-à-vis positivist studies, it also requires a minimal internal flexibility to facilitate a lively debate regarding its own ontological, epistemological and methodological presuppositions. For instance, Klein and Myers [2] identify hermeneutics as the main form of interpretivism, acknowledging that postmodernism and deconstructionism are fundamentally different forms. Furthermore, IS research, different from both positivist and interpretivist research, can also be classified as critical [3]. Critical research signifies research in which social critique constitutes the main task, which means bringing to light the restrictive and alienating conditions of the status quo [2]. Critical research is emancipatory [4] and assumes that people, including the researcher, can consciously act to change their social and economic conditions.

In this paper I would particularly like to explore the potential of process theorizing, which means a mode of theorizing which is not merely about interpreting its object (technology in organizations), but thinks beyond its object [5], with the value of a critical intervention. More specifically, the aim of this paper is to reinvigorate the 
debate about the meaning of materiality. Shall we complement the corpus of sociomaterial studies with a suitable framework to think beyond interpretivism and study the materiality of the affective register? What are the notions which would gain currency from an ideological critique of work practices? The main contribution of this paper is to complement existing accounts of ideology in the literature of technology in organizations by introducing the notion of the "materiality of the signifier" and "ideological fantasy" to complement and enrich existing sociomaterial studies.

The paper is organized as follows. Firstly, language and materiality will be posited as the two poles of this debate, with sociomateriality as a dominant way of overcoming this opposition. Secondly, this paper will highlight the deficits of the materiality of the affective register in existing accounts of sociomaterial studies. The traditional articulation between the social and the material indeed conceals another articulation between the affective and the discursive. Finally, this paper will draw on authors such as Lacan, Althusser and Butler and the Essex Lacanian School (Laclau, Glynos) to propose a radical approach and to provide an adequate language for those researchers seeking to grasp the articulation of the affective and the discursive.

\section{Language and Materiality}

Technology, as well as its design and use, is not merely functional but also the product and subject of language. Thus, debates on the relationship between discourse and materiality highlight the plenum of agencies associated with technology.

As a response to deterministic positivist studies conferring materiality with a strong causal force, interpretive studies emerged in the 1970s and 1980s with a different agenda, focusing more attentively on social dynamics, the social context and human aspects, and on why people and organizations respond differently to computers. Language and materiality typically become the two poles of these debates. After the linguistic turn which occurred in the social sciences, following the influence of Wittgenstein, the structuralist linguist Saussure and subsequently Derrida, linguistic methods have progressively penetrated into the field of organizational studies [6] in response to the hegemony of positivist studies in management research. These studies tend to address issues such as communication or discourse themselves, as distinct from materiality.

However, communicative, discursive or linguistic explanations have been accused of "exaggerating the muscle of symbolism" [7] (p. 24). Post-structuralist thinking is typically reduced by orthodox Marxists, positivists, critical realists or actor-network theorists to a fashionable form of linguistic idealism, naively fascinated by the "free play of signifiers" [8] (p. 125) and abstractly disconnected from materiality. At the other end of the spectrum, neo-materialist thinkers such as Latour, in open dispute with the linguistic turn [9], accuse this linguistic idealism (also known as postmodernism) of having marginalized objects. Latour is the architect of the hybridation of the social, the discursive and the material. A way for him to cut the Gordian knot between the three was to coin the hybrid notion of "quasi-objects", drawing on the work of Michel Serres. Such studies progressively cohered and paved the way for the theoreti- 
cal movement of social constructivism in the 1990s, a movement which can be divided into two streams [10]. The first is the field of science and technology studies (STS), which examines the social processes during the design and development process $[11,12,13,14]$ From this perspective, interpretivism leads researchers to research themselves and critically assess the assumptions and theoretical constructs underlying their scientific discipline and practice [1]. The second stream, the field of organizational and information studies, studies technology's implementation in organizational contexts, drawing heavily on Giddens' structuration theory [15, 16, 17].

How is the notion of materiality applied to the context of work? Various researchers have attempted to connect discourse and materiality in order to materialize organizational communication through the lens of practice. Thus, IS and organizational scholars have posited the notion of sociomateriality to address the significant neglect of technology in the interpretive information systems literature. Sociomateriality consequently emphasizes the ontological inseparability of objects from their context, which means that there is no social action that does not entail a material means. As Orlikowski and Scott argue [18] (p. 456): "Any distinction between humans and technologies is analytical only, and done with the recognition that these entities necessarily entail each other in practice". In other words, a sociomaterial ontology highlights the constitutive entanglement between the social and the material:

The sociomaterial view asserts that materiality is integral to organizing, positing that the social and the material are constitutively entangled in everyday life. A position of constitutive entanglement does not privilege either humans or technology

... Instead, the social and the material are inextricably related - there is no social that is not also material, and no material that is not also social. [19] (p. 1437)

Thus, work researchers within the practice turn have a performative view of social and organizational phenomena such as knowledge, human activity and sociality: "Our world is increasingly in flux and interconnected, a world where social entities appear as the result of ongoing work and complex machinations" [20]. Technologies are constructed with particular material properties (hardware, software, techniques) and are inscribed with the developer's assumptions at a particular point in time. Thus, while Orlikowski et al. [21] underscore the role of images, descriptions, rhetoric and ideologies held by intermediaries such as translators, vendors, journalists, consultants, champions, trainers and managers, they provide no account of their materiality.

Thus, some dimensions of sociomaterial practice are foregrounded, especially the materiality of technology, while others, especially the affective and embodied dimension of social practices, are backgrounded or ignored. In this regards, the notion of sociomateriality can be questioned.

\section{A Critical Evaluation of Sociomateriality}

There has been a general lack of attention paid to discourse and affect in the study of the relationships between artifacts/objects and human activity among IS scholars. This is particularly the case with the sociomateriality movement, which holds that materiality does matter, but affect and identity much less so. 
In the organizational field, recent sociomaterial discussions about the materiality of objects have not addressed the role of subjectivity in sociomaterial entanglement. The problem is succinctly expressed by Jones:

These accounts, however, employ several different terms, sometimes interchangeably, to characterize the nature of this entanglement, such as inseparability, interpenetration, relationality, and embodiment, and to refer to what is entangled, for example the social and the material, humans and technology, work and technology. While such variation may be justified on aesthetic or stylistic grounds, treating these terms as synonyms may be seen as conflating different ontological claims. [22] (p. 197)

In particular, the sociomateriality literature uses the "materiality" of the body and that of technology interchangeably, yet simultaneously neglects the affective and embodied dimensions of practices within existing formulations of sociomateriality. A good example of the specificity of the body is that bodies reject the word of symbolism by enduring pain, injury, illness, death, hunger, reproduction and ageing [23]. This is of particular importance in management studies where disembodied structures such as strategy, institutions or corporate governance have prevailed historically [7]. Furthermore, our sense of being a person, in other words our identity, is a symbolic construction which never precisely matches our physical body. As Burkitt [24] argues, there is always a gap between self-image and appearance. This is especially noticeable in pathologies such as anorexia, where the subject is convinced that he/she is fat, whereas everybody else perceives the opposite.

What is more, while bodies and embodied actions are arguably neglected in accounts of sociomateriality [25], the place of embodiment is nevertheless recognized more broadly among agential humanists. Thus, subjective notions of competence and identity can be understood as navigated corporeality. For instance, Suchman refers to embodied competencies, actions, practices, work, labours and knowing [26] - for example a nurse's dexterity in performing tasks [22]. In Schatzki, cognitive capacities, activities and understandings are all identified as being embodied [27]. Alternative body-sensitive approaches do exist, such as Reckwitz's definition of practice: "forms of bodily activities, forms of mental activities, 'things' and their use, a background knowledge in the form of understanding, know-how, states of emotion and motivational knowledge" [28] (p. 249). Furthermore, as Reckwitz says, "every practice contains a certain practice emotionality" such for examples the compassion or relational support of a nurse caring for patients [28] (p. 254).

Furthermore, objects generate and organize affectivity. Rheinberger sheds light on the power of material objects, arguing that objects are "open-ended" and operate as a source of interest and motivation by virtue of their "opacity, their surplus, their material transcendence", which is "what arouses interest in them and keeps them alive as targets of research" [29] (p. 406). This particular power of objects has been also analysed by Knorr Cetina [30, 31], who asserts that the source of this power stems from the subject's lack of completeness, which generates energy and emotional investment on the part of the developers. The attempt to "fill this void fuels the attachment for the object, but also paradoxically specifies ever further issues and the sense of lack, so that the process is self-fueling" [32] (p. 7). 
However, object theorists tend to anthropomorphize properties of the object - it is not clear whether the "surplus" belongs to the objects or to their users' perceptions. Typically, object studies, influenced by actor-network theorists, have metaphorically let the objects talk, liberated and translated their speech and then provided them with the legitimacy which they had historically lost in modern times. Actor-network theory (ANT) is anthropomorphic in its attempt to provide objects not only with speech, but also with a "parliament of things" [9] (p. 142). In that sense, as an extension of Latour's metaphor, the sociologist would not merely be a puppeteer [33], but also a ventriloquist (this image is also used by Cooren [34]). Yet it is not clear what it is that speaks, i.e. what instance fundamentally mediates the technology's words and claims?

The materiality of the body and associated aspects of organizational practices, including affects, also lead us to address questions of power relations and domination. This is regarded by certain practice theorists as a promising research avenue [35], [25]. This issue raises the problem of the articulation of the material and the discursive. In addition, we should bear in mind that the body is not only the locus of agency and affective response, but also the target of power and normalization [20]. For example, Nicolini calls for further research exploring the relationship between siteness, knowing in practice and power:

The idea that the site of knowing is always a specifically organized arrangement of practices reminds us that looking at knowing in practice necessarily requires addressing issues of interests, conflict, and power. This, in turn, necessitates being attentive to [...] how deviance and resistance manifest themselves and are dealt with, and how normalcy is pursued through the attempt at making these differences disappear through material and discursive practices of hegemonic closure and "suturing". [36] (p. 616)

Specific knowing regimes are thus produced and performed in practice and through practice. However, the use of the word material in Nicolini's sentence is ambiguous, as it bears very different ontological presuppositions in Laclau's discursive theory of subjectivity (see [37]) and in object studies drawing on ANT.

In his overview of practice theories [20], Nicolini indeed distinguishes between two groups of authors in terms of the prominence they confer to discursivity - a distinction which reproduces the humanist/realist divide. On the one hand, authors belonging to the so-called contemporary Heideggerian and Wittgensteinian tradition, including Schatzki, Rose, Pickering [38] and Laclau and Mouffe, postulate that intelligibility presides over the functioning of practice; on the other hand, authors such as Giddens, Bourdieu, Barad or Latour are much more skeptical, for various reasons, as regards the potentiality of human intentionality.

In fact, Nicolini's scholarship does address affect, identity and subjectivity only in passing; he does not draw the ontological consequences of the link between the material and the discursive, and he relegates notions of collective representation or ideology to an old structuralist tradition, where the horizon of intelligibility was the causal "motor of conduct and the trigger of emotions" [20] (p. 173). 


\section{$4 \quad$ Ideology and Materiality}

The study of ideology is too often conflated with idealism and determinism. What is missing in the literature is an account of ideology as materiality. I will illustrate this claim by discussing the interpretations offered of Braverman's study of ideology.

Ashcraft et al. [7] convincingly explore this complexity of materiality in a summary of the various forms of materiality in organizations, specifically in the context of communication, by introducing a distinction between discourse as material force or discourse exerted on material masses. Let us illustrate this with a classic study in IS. In Labor and Monopoly Capital, Braverman [39] argues that technologies deskill workers because, all else being equal, managers and staff choose designs and labour processes which divorce work from its execution. This is in fact the inevitable outcome of a dominant managerial ideology rooted in Babbage's principle of division of labour in the early nineteenth century and Taylor's scientific management. One symptomatic element is that the existing constructivist literature in IS [40], [10] tends to classify Marxist "deskilling" theorists, such as Braverman, as altogether deterministic and idealistic. According to Orlikowski and Barley:

Unlike a strict materialist, he argued that American management's ideology of control determined which designs were commissioned and deployed [...] Braverman told a decidedly deterministic story of $\mathrm{NC}$ tools' effects and his analysis, in retrospect, unwittingly hinged on the technical specifics of the type of NC tools used at the time he wrote. [40] (p. 150)

Thus, based on the above, Braverman would tell a "deterministic story". This is perhaps unfair, given that the critical (and even revolutionary) ambition of Marxist theory has a very concrete transformative ambition. Orlikowski and Barley contest the primacy of ideology perhaps because they have a classic understanding of what ideology means. Deconstruction is in fact the necessary step which precedes construction: it is the necessary opening up of a new space of possibility, in which the new can emerge.

The second argument is that Braverman was not a "strict materialist". The trap of the exercise of Marxist critique is indeed to fall into conspiracy theory, which means overemphasizing the intentionality behind action, making connections without material evidence. Prolonging the Marxist discussion on the material reproduction of the conditions of production, Althusser [41] argues that this involves not only the reproduction of the means of production (the machines), but also the reproduction of labour-power (the people). The crucial point to us here is that reproduction is not automatic and always relies on "living labour" [42] (p. 263), which means the possibility for labour-power to refuse the injunction to work. From the former perspective, Braverman is clearly materialist by rendering contestation and an emancipatory project possible.

What is missing from Braverman and the classic definition of ideology is an account of ideology as materiality. In this paper, my objective is to explore, beyond sociomaterial interpretivism, a view which decouples technology from materiality. This proposed view is neither deterministic, as is the case with positivist studies, nor materialist in the sense that is usually ascribed to this word in the sociology of scien- 
tific knowledge. A view of ideology as materiality is crucial because non-materialist reading of Braverman tends to ignore the material dimension that his contestation of scientific management in practice can bear. Finally, this critical or deconstructionist view challenges various core principles of interpretivism, namely the neutrality of the researcher and the principle of his/her non-intervention.

Thus far we have identified the underexplored materiality of discourse, affect and the body in existing sociomaterial studies. Affect is the notion which is absent in the existing theory of ideology at work to rematerialize ideology.

\section{$5 \quad$ Rematerializing Ideology}

A radical approach will now be elaborated, one which complements the traditional dichotomy between materiality and sociality by shedding light on the relationship between affect and ideology. From this perspective, ideology is not a corpus of text, but is embodied in our behaviour and rituals.

\subsection{The Essex Lacanian School}

This paper draws now on a corpus of authors who have thus far been insufficiently mobilized in organization theory, whereas these authors have a great potential for taking ideology seriously and studying how it affects sociomaterial work practices.

The Essex School of Discourse Analysis is a group of political theorists from Essex University, gathered around the figure of Laclau, who mobilize the postLacanian theory of ideology (including authors such as Butler) to study discursive phenomena in the political field. These authors, despite evolving in the Anglo-Saxon world, also draw heavily on French authors such as Althusser and Lacan. In what follows, I will demonstrate that much is to be gained by returning to the work of these theorists and by bringing ideology back into the study of technology in organizations. From this (Laclauian) perspective, social practices are primarily characterized by a state of "radical contingency" [43]; the reasons why people accept to engage in practice are never entirely sutured, and can always be challenged. Social processes are never entirely routinized, determined or mechanistic, but always depend on their subjective integration to function. Thus, the way we make sense of a practice is absolutely central to its functioning. The purpose of such an analysis is therefore to disclose this ontological contingency and to reveal how it is significant in shaping the actors" "ongoing affective identification with practices" [44] (p. 2) and the way their behaviours reproduce, contest or restore these practices. These subjective acts materialize the "trace of contingency within the structure" [45] (p. 435).

As we have seen, pluralistic approaches, known as practice theories, have highlighted the sociomaterial ontology and the inseparability of the material and the social. While practices are social and material, they are also affective and linguistic; thus, this affective identification with technology needs to be further explored. The subjective processes motivating the ritualization of everyday practice are undertheorized in IS. More importantly, this neglect is regrettable, as a focus on affect, 
subjectivity and signification would enable the rematerialization of the linguistic approach to organizations, thereby addressing issues including discourse, communication and ideology in a way which is more aligned with their subject-based roots. This ontological link between the affective and discourse is for instance absent in Hardy and Thomas's account [46]; by contrast, the Essex Lacanian School is typically helpful in addressing the "affective turn" [47] in the study of materiality in organizations and information studies. This aspect is necessary for any radical approach to work studies, namely addressing the roots of IS and organizational phenomena, given the Latin etymology of the word (radix means root).

The following section seeks to discuss the materiality through which a subject copes with the determination of meaning, negotiates with it and keeps it at distance through discourse; this is the place of human agency, where contestation and resignification are located.

\subsection{Materiality of the Signifier}

Based on the above, we can understand that the meaning ascribed to a practice has deep implications for the way in which people accept to identify and engage with it. However, what is the process through which meaning may affect our subjectivities and our identification with practice?

Identity, for Lacan, involves being desired by others and gaining recognition [48]. The "subject-in-meaning" [48] is constructed before the actual birth of the individual, for instance when a name is chosen. This recalls an important tenet of Lacanian theory, namely the importance of the name in the construction of identity. The name precedes the subject and provides it with a discursive place [49] (p. 55). The name is also the bearer of a string of meanings, and it is already invested with the desires of others. Let us consider a provincial name or an aristocratic name which bear different connotations. Identity can be read as a signifying practice: there are certain signifiers to which a subject becomes fixated. Certain signifiers matter more than others for the subject, and these signifiers contribute to the identity of the subject.

For Althusser, the determination of identity occurs through the interpellation of the subject by dominant discourses, metaphorically akin to a police officer embodying the Law, who interpellates a man in the street [41]. Althusser's argument of interpellation means that we are hailed, named and recognized through language, and our identity is constantly negotiated between subjectivity and interpellations. As a response to the structuralist stance in Althusser's work, Judith Butler in Excitable Speech argues that there is no reason why we should accept society's identification of us - the interpellation - as a particular sort of subject [50].

Thus, Butler imagines the following scene: the man in the street who is named, resists and protests about the name. Consequently, the interpellation misses its mark: "This is not me, you must be mistaken". The subject deals with the interpellation, negotiates with it, and identity is constituted by discourse, albeit at a certain distance from it. What is more, the interpellation might not have a speaker, yet it may take other insidious forms materialized through artifacts such as bureaucratic paperwork, adoption papers, employment application forms or gender categories [50]. The words 
by which we are hailed are rarely those we ourselves would choose; they may be traumatic or excitable, although there is always room for contestation and resignification located in human agency.

From this perspective, there is always a primacy of the subject over the interpellation, a primacy of the signifier over the signified, in linguistic terms, which is captured by the notion of "the materiality of the signifier" $[51,52,53]$.

The materiality of the signifier (a materiality that comprises both signs and their significatory efficacy) implies that there can be no reference to a pure materiality except via materiality. Hence, it is not that one cannot get outside of language in order to grasp materiality in and of itself; rather, every effort to refer to materiality takes place through a signifying process which, in its phenomenality, is always already material. In this sense, then, language and materiality are not opposed, for language both is and refers to what is material, and what is material never fully escapes from the process by which it is signified [51] (p. 37).

This fundamental autonomy of the signifier, the "sliding of the signified under the signifier" [53] (p. 71), is the condition for subjectivity to manifest its potential/power and its capacity of subversion, parody or displacement of meaning [51]. The switch from signified/signifier to signifier/signified is precisely where Lacanian theory departs from Saussurean semiotics, which has inspired studies in our field [54, 55]. Thus, the materiality of the signifier captures both signs and their "significatory efficacy" (Butler [50]), the signifier's retroactive affective effect on us, in a more central way than existing formulations of symbolic interactionism (e.g. [56]). This fundamental autonomy of the signifier is the condition for subjectivity to manifest its arbitrary power, its power to act [57] and its capacity of subversion, parody or rewriting [58].

This account is crucial, as it responds to the need to revitalize sociomaterial studies [7], [59], [60]. This does not mean negating the technicalities of technology, but rather that these are always already constituted within language. It means recognizing the status of technology not merely as a material artifact, but also as a material signifier which bears meaning in our life. The materiality of the signifier differs from the materiality of the referent (the object of discourse) and the materiality of the signified (its imaginary meaning). This is not tantamount to equating technology with discourse; instead, it implies that there is no reference to technical materiality which escapes the mediation of affective and discursive process.

In the following section, I will demonstrate how this corpus of authors offers a great potential to study work practice and technology in organizations. To do so, I will re-embrace the study of ideology in the workplace.

\subsection{Reframing Ideology}

To achieve the objective of this paper, namely to name and identify the play of affect and discourse, ideology needs to be rematerialized. This will lead me to introduce the notion of ideological fantasy to foreground the materiality of the affective register.

Ideology and Practice. One of Althusser's main contributions to Marxist theory is rematerializing the notion of ideology by radically rejecting Marx's assumption that 
ideology is a "false consciousness", a systematic illusion which has no history [41]. Thereby, he emphasizes the polysemy of materiality or matter:

An ideology always exists in an apparatus, and its practices, or practices. This existence is material. Of course, the material existence of the ideology in an apparatus and its practices does not have the same modality as the material existence of a paving-stone or a rifle. But at the risk of being taken for a Neo-Aristotelician (NB Marx had a very high regard for Aristotle), I shall say that "matter is discussed in many senses", or rather that it exists in different modalities, all rooted in the last instance on "physical" matter. [41] (p. 40)

The materialities of a displacement for going to a Mass or a stadium, of kneeling down, of singing a national anthem, of a prayer, of an act of contrition, of a gaze, of a handshake, of an external verbal discourse or in "internal" verbal discourse (consciousness), are not one and the same materiality. Consciousness itself becomes material and the notion of idea itself disappears from his framework (Althusser [41]). This is a crucial point: affect is not added to signification, but is "consubstantial with it" [61] (p. 326). The notions of subject, consciousness, belief and action remain. In addition, the new terms of "practices", "rituals" and "ideological apparatus" emerge.

Thus, Althusser's performative chain of determination of the subject can be read thus: the material ideological apparatus prescribes the material practices governed by a material ritual, practices which exist in the material actions of a subject acting in all consciousness according to his beliefs [41]. From this perspective, Althusser is more concerned with the "organization of thought", through ideological apparatus, rather than "thinking about organizations" by essentializing this notion [62]. Put another way, Althusser sees ideology as an organization of signifying practices whose function it is to turn individuals into subjects, and thereby provide them with a social and political identity. This standpoint adopted by Althusser fits Nayak's claim that process theory is not abstract but empirical; it doesn't exist but acts, it contributes to the process of provoking thinking to "think beyond" [5].

In this way, Laclau has elaborated an ontological definition of ideology, which is a condition for rematerializing ideology. Far from reducing ideology to "false consciousness", Laclau has inverted the old Marxist proposition. Thus, Laclau's theory maintains the Marxist concept of ideology and the category of misrecognition by inverting their content. Laclau's theory can therefore be described as post-Marxist because of its anti-essentialism:

The ideological would not consist of the misrecognition of a positive essence [an illusion as to real class interests, for example], but exactly the opposite: it would consist of the non-recognition of the precarious character of any positivity, of the impossibility of any ultimate suture. [63] (p. 92)

In other words, the invisibility of contingency is constitutive of the ideological misrecognition, and the critical intervention aims to render contingency visible. The critical intervention (the signifier) redefines and contests the dominant interpellation (the signified). The key idea here is that the deviation from Marxist theory of ideology is not only epistemological in nature, but also ontological: ideology is not an illusion, 
as in false consciousness, but pertains to the way any social reality itself is constituted.

Ideological Fantasy in Work Studies. To criticize an ideology, it is not enough to criticize a discourse or a text and to stay at the level of intentionality; we need to comprehend ideology not as a cognitive process, but rather as an affective cement or a glue [64]. Burawoy is an organizational theorist who has conceptualized consent at work as being subordination to a ruling ideology. At the time of Burawoy, the site of the antagonism between labour and capital happened to be the factory floor:

People do not carry ideologies around in their heads. They carry theories, knowledge, attitudes, in the form of consciousness. These become an ideology, "a material force once it has gripped the masses." Ideology is neither a "cold utopia" nor "learned theorizing" but a "creation of concrete phantasy which acts on the dispersed and shattered people to arouse and organize its collective will". Ideology acts as a cement for social relations; it binds individuals to one another; it connects immediate experiences to each other, to the past, and to the future. [65] (p. 18, emphasis added).

Burawoy is here citing Althusser's work [66] (p. 168), which is seminal to the understanding of ideology as materiality. Burawoy is interested in why people accept having to work as hard as they do. In other words, he explores the concrete operation of ideology though which painful labour is made acceptable and ends up not being contested [65]. This occurs through the informal game of "making out" in the factory, which means making an acceptable percentage output, one not higher than $140 \%$ and not lower than $125 \%$. When the chances of winning are too high, the game degenerates into "boredom", but when the uncertainty is too great, the game becomes "frustrating" [65] (p. 87). To function effectively and absorb the operators without diminishing returns, "making out" needs to keep the excitement intact, otherwise it falls into a crisis of "motivation" or "legitimation" [65] (p. 87).

This ideology which "acts as a cement", in other words this affective grip, is precisely what the Essex Lacanian School has explored in its most recent work by foregrounding the notion of "ideological fantasy". Burawoy, quoting Althusser, defines ideology as "a concrete phantasy which acts". In Glynos' words, it is not the description of ideology's content which matters, but rather its "capacity to account for an ideology's grip, its power to transfix subjects" [64] (p. 192), that is, the way ideology manages to exert its hold over us. Studies of workplace practices need to focus on ideological fantasies, as it is not enough to understand the discursive patterns if we wish to make sense of social practice: we must also analyse the degree of "libidinal investment" they arouse in the relevant actors [67]. There is indeed a research avenue addressing the power of fantasies to structure the motivations underpinning many economic and production practices [e.g. 68, 69, 70, 71]. These studies, most frequently positioned within the field of critical management studies and inspired by the Essex Lacanian School, typically scrutinise workplace practices in terms of fantasmatic logic. Rather than describing the content of the fantasy, these studies look more specifically at the mode of attachment of social actors to their fantasy: the greater the attachment to and dependence on the fantasy, the stronger the ideological grip [72]. When a subject is overinvested in a fantasy, any attempt to 
destabilize the subject's fantasy narrative will be experienced as a threat and will generate anxiety [72].

\section{Conclusion}

In this paper I have questioned the notion of sociomateriality by shedding light on the ontological contingency which characterizes the social norms that sustain practices. The ontological stance adopted here complements certain formulations of practicebased studies, for which notions such as contingency or re-signification are not immediately relevant, given that practice theory, as a genre, is the study of mundane activity, not specifically of its transformation. To address this issue, I have proposed a Lacanian approach, which considers ideology beyond linguistic idealism, and materiality beyond technological solutionism. I avoid any accusation of idealism by demonstrating that ideology is better understood by incorporating the affective dimension carried by discourse as a concrete signifying practice, which acts by interpellating subjects and by producing affective identification. Organizational and information studies can be better understood by acknowledging the materiality of the signifier, the way signification shapes behaviour and taken-for-granted practices. Furthermore, I have elaborated on the materialist theory of ideology as conceptualized by Althusser and applied to organizational theory by Burawoy. This notion is especially helpful for researchers seeking to provide critical explanations of how and why technology-in-practice is made vulnerable, obsolete and re-signified. Furthermore, the understanding of the materiality of the signifier and ideological fantasy are crucial in IS in order to autonomously frame issues such as consent at work, an issue which is becoming more important than ever in data-driven organizations.

\section{References}

1. Walsham, G.: The Emergence of Interpretivism in IS Research. Information Systems Research. 6(4), 376-394 (1995)

2. Klein, H.K., Myers, M.D.: A Set of Principles for Conducting and Evaluating Interpretive Field Studies in Information Systems. MIS Quarterly. 23(1), 67-94 (1999)

3. Chua, W.F.: Radical Developments in Accounting Thought. The Accounting Review. (61), 601-632 (1986)

4. Alvesson, M., Willmott, H.: On the Idea of Emancipation in Management and Organization Studies. Academy of Management Review. 17(3), 432-464 (1992)

5. Nayak, A.: On the Way to Theory: A Processual Approach. Organization Studies. 29(2), 173-190 (2008)

6. Alvesson, M., Karreman, D.: Varieties of Discourse: On the Study of Organizations through Discourse Analysis. Human Relations. 53(9), 1125-1149 (2010)

7. Ashcraft, K.L., Kuhn, T.R., Cooren, F.: Constitutional Amendments: Materializing Organizational Communication. The Academy of Management Annals. 3(1), 1-64 (2009) 
8. Dreyfus, H., Rabinow, P.: Michel Foucault: Beyond Structuralism and Hermeneutics. University of Chicago Press, Chicago (1982)

9. Latour, B.: We Have Never Been Modern. Harvard University Press, Cambridge, MA (1993)

10. Leonardi, P.M., Barley, S.R.: What's Under Construction Here? Social Action, Materiality, and Power in Constructivist Studies of Technology and Organizing. Academy of Management Annals. 4, 1-51 (2010)

11. Callon, M.: The Sociology of an Actor-Network: The Case of the Electric Vehicle. In: Callon, M., Law, J., Rip, A. (eds) Mapping the Dynamics of Science and Technology. Macmillan, London (1986)

12. Klein, H.K., Kleinman, D.L.: The Social Construction of Technology: Structural Considerations. Science Technology \& Human Values. 27(1), 28-52 (2002)

13. Latour, B.: Science in Action: How to Follow Scientists and Engineers through Society. Harvard University Press, Cambridge, MA (1987)

14. Pinch, T.J., Bijker, W.E.: The Social Construction of Facts and Artifacts or How the Sociology of Science and the Sociology of Technology Might Benefit Each Other. Social Studies of Science. 14(3), 399-441 (1984)

15. Orlikowski, W.J.: The Duality of technology: Rethinking the Concept of Technology in Organizations. Organization Science. 3(3), 398-427 (1992)

16. DeSanctis, G., Poole, S.M.: Capturing the Complexity in Advanced Technology Use: Adaptative Structuration Theory. Organization Science. 5(2), 121-147 (1994)

17. Jones, M., Karsten, H.: Giddens' Structuration Theory and Information Systems Research. Management Information Systems Quarterly. 32(1), 127-157 (2008)

18. Orlikowski, W.J., Scott, S.V.: Sociomateriality: Challenging the Separation of Technology, Work and Organization. Academy of Management Annals. 2, 433-474 (2008)

19. Orlikowski, W.J.: Sociomaterial Practices: Exploring Technology at Work. Organization Studies. 28(9), 1435-1448 (2007)

20. Nicolini, D.: Practice Theory, Work and Organization: An Introduction. Oxford University Press, Oxford (2012)

21. Orlikowski, W.J., Yates, J., Okamura, K., Fujimoto, M.: Shaping Electronic Communication: The Metastructuring of Technology in Use. Organization Science, 6(4), 423-444 (1995)

22. Jones, M.: Untangling Sociomateriality. In: Carlile, P.R., Nicolini, D., Langley A., Tsoukas, H. (eds) How Matter Matters: Objects, Artifacts, and Materiality in Organization Studies, 197-226. Oxford University Press, Oxford (2013)

23. Rich, K., Rumens, N., Tyler, M.: Un/doing Chrononormativity: Negotiating Ageing, Gender and Sexuality in Organizational Life. Organization Studies. 35(11), 1677-1698 (2014)

24. Burkitt, I.: Bodies of Thoughts: Embodiment, Identity \& Modernity. Sage, London (1999)

25. Jones, M.: A Matter of Life and Death: Exploring Conceptualizations of Sociomateriality in the Context of Critical Care. MIS Quarterly. 38(3), 895-925 (2014)

26. Suchman, L.: Human-Machine Reconfigurations. Cambridge University Press, Cambridge (2007)

27. Schatzki, T.R., Knorr Cetina, K., Von Sabigny, E.: The Practice Turn in Contemporary Theory. Routledge, London (2001)

28. Reckwitz, A.: Toward a Theory of Social Practices: A Development in Culturalist Theorizing. European Journal of Social Theory. 5(2), 243-263 (2002) 
29. Rheinberger, R.-H.: A Reply to David Bloor: "Toward a Sociology of Epistemic Things". Perspectives on Science. 13(3), 406-410 (2005)

30. Knorr Cetina, K.: Sociality with Objects: Social Relations in Postsocial Knowledge Societies. Theory, Culture \& Society. 14(4), 1-30 (1997)

31. Knorr Cetina, K.: Epistemic Cultures: How the Sciences Make Knowledge. Harvard University Press, Cambridge, MA and London (1999)

32. Nicolini, D., Mengis, J., Swan, J.: Understanding the Role of Objects in Multidisciplinary Collaboration. Organization Science. 23, 612-629 (2012)

33. Latour, B.: Reassembling the Social: An Introduction to Actor-Network-Theory. Oxford University Press, Oxford and New York (2005)

34. Cooren, F.: Communication Theory at the Center: Ventriloquism and the Communicative Constitution of Reality. Journal of Communication. 62(1), 1-20 (2012)

35. Contu, A., Willmott, H. Re-embedding Situatedness: The Importance of Power Relations in Learning Theory. Organization Science. 14(3), 283-297 (2003)

36. Nicolini, D.: Practice as the Site of Knowing: Insights from the Field of Telemedicine. Organization Science. 22(3), 602-620 (2011)

37. Laclau, E., Mouffe, C.: Post-Marxism Without Apologies. New Left Review. 166, 79-106 (1987)

38. Pickering, A.: The Mangle of Practice. University of Chicago Press, Chicago, IL (1995)

39. Braverman, H.: Labor and Monopoly Capital: The Degradation of Work in the Twentieth Ventury. Monthly Labor Review Press, New York (1973)

40. Orlikowski, W.J., Barley, S.: Technology and Institutions: What can research in Information Technology and Research on Organizations Learn from each other? MIS Quarterly. 25(2) 145-165 (2001)

41. Althusser, L.: On Ideology. Verso, London (1971)

42. Marx. K.: Grundrisse. Trans. Martin Nicolaus. Vintage. New York (1973)

43. Laclau, E., Mouffe, C.: Hegemony and Socialist Strategy: Towards a Radical Democratic Politics. Verso, London and New York (1985)

44. Thompson, M., Willmott, H.: The Social Potency of Affect: Identification and Power in the Immanent Structuring of Practice. Human Relations. 69(2), 483-506 (2015)

45. Laclau, E.: Discourse. In: Goodin, R.E., Pettit, P. (eds) A Companion to Contemporary Political Philosophy, pp. 431-437. Blackwell, Oxford (1993).

46. Hardy, C., Thomas, R.: Discourse in a Material World. Journal of Management Studies. 52(5), 680-696 (2014)

47. Clough, P.T.: The Affective Turn: Political Economy, Biomedia and Bodies. Theory Culture \& Society. 25(1), 1-22 (2008)

48. Lacan, J.: The Seminar, Book IX: L'Identification. Unpublished (1961)

49. Pluth, E.: Signifiers and Acts: Freedom in Lacan's Theory of the Subject. SUNY Press, New York (2007)

50. Butler, J.: Excitable Speech: A Politics of the Performative. Routledge, London and New York (1997)

51. Butler, J.: Bodies that Matter: On the Discursive Limits of "Sex". Routledge, London and New York (1993)

52. Lacan, J., Fink, B.: Ecrits: The First Complete Edition in English. W.W. Norton \& Co., New York (2006)

53. Butler, J., Laclau, E., Žižek, S.: Contingency, Hegemony, Universality: Contemporary Dialogues on the Left. Verso, London and New York (2000)

54. Barley, S.R.: The Codes of the Dead: The Semiotics of Funeral Work. Urban Life. 12(1), 3-31 (1983) 
55. Bailey, E.D., Barley, R.S., Leonardi, M.P.: The Lure of the Virtual. Organization Science. 23(5), 1485-1504 (2011)

56. Prasad, P.: Symbolic Processes in the Implementation of Technological Change: A Symbolic Interactionist Study of Work Computerization. Academy of Management Journal. 36(6), 1400-1429 (1993)

57. Negri, P.: Value and Affect. Boundary 2. 26(2), 77-88 (1999)

58. Fotaki, M., Metcalfe, B.D., Harding, N.: Writing Materiality into Management and Organization Studies through and with Luce Irigaray. Human Relations. 67(10), 12391263 (2014)

59. Leclerq-Vandelannoitte, A.: Organizations as Discursive Constructions: A Foucauldian Approach. Organization Studies, 32, 1247-1271 (2011)

60. Robichaud, D., Cooren, F.: Organization and Organizing: Materiality, Agency and Discourse. Routledge, Abingdon (2013)

61. Laclau, E.: Glimpsing the Future: A Reply. In: Critchley, S., Marchart, O. (eds) Laclau: A Critical Reader, pp. 279-328. Routledge, Abingdon and New York (2004)

62. Chia, R.: Organizational Analysis as a Deconstructive Practice. Walter de Gruyter, Berlin (1996)

63. Laclau, E.: New Reflections on the Revolution of Our Time. Verso, London and New York (1990)

64. Glynos, J.: The Grip of Ideology: A Lacanian Approach to the Theory of Ideology. Journal of Political Ideologies. 6(2), 191-214 (2001)

65. Burawoy, M.: Manufacturing Consent: Changes in the Labor Process Under Monopoly Capitalism. University of Chicago Press, Chicago (1979)

66. Althusser, L.: Lenin and Philosophy and Other Essays. New Left Books, London (1971)

67. Ekman, S.: Fantasies About Work as Limitless Potential: How Managers and Employees Seduce Each Other through Dynamics of Mutual Recognition. Human Relations. 66(9), 1159-1181 (2013)

68. Cederström, C., Grassman, R.: The Masochistic Reflexive Turn. Ephemera. 8(1), 41-57 (2008)

69. Kenny, K.: Someone Big and Important: Identification and Affect in an International Development Organization. Organization Studies. 33 (9), 1175-1193 (2012)

70. Sköld, D.: An Evil King "Thing", Rising, Falling and Multiplying in Trucker Culture. Organization. 16(2), 249-266 (2009)

71. Sköld, D.: The Other Side of Enjoyment: Short-Circuiting Marketing and Creativity in the Experience Economy. Organization. 17(3), 363-378 (2010)

72. Glynos, J.: Ideological Fantasy at Work. Subjectivity. 13(3), 275-296 (2008) 